\title{
Dose Regimen
}

National Cancer Institute

\section{Source}

National Cancer Institute. Dose Regimen. NCI Thesaurus. Code C71137.

A treatment plan that specifies the amount, schedule, and the duration of intervention(s). 